\title{
Politics could hamper FDA reform
}

By setting WASHINGTON, D.C.--In the musical version of reforming the U.S. Food and Drug Administration (FDA, Rockville, MD), leaders from both major parties in Congress are now mostly singing the same notes. Even top officials in the Clinton Administration say they are "walking a line," trying to assure the safety of food and drug products while "minimizing" regulatory burdens. Nevertheless, disagreements over the federal budget and the looming 1996 presidential campaign could upset the momentary harmony.

FDA reform is a "more subtle issue" than drug price controls, the dominant theme during 1994 , says Henri Termeer, chairman of the Biotechnology Industry Organization (BIO, Washington, DC) and president of Genzyme Corp. (Cambridge, MA), who spoke during BIO's conference in the capital. "But it is no different in impact. It can change what we in the biotechnology industry do dramatically. . by lowering the cost of discovery and the time it takes to get our products through the agency and approved."

Senator Nancy Kassebaum (RKS), who chairs the U.S. Senate Committee on Labor and Human Resources, is leading what needs to become a consensus effort for writing and passing a reform bill, according to committee staff member Jane Williams. Williams and other congressional staff members agree that legislation is needed to "clear away the underbrush" and to correct practices that FDA officials no longer can fix by making simpler administrative changes within the agency.

Much of the impetus behind this reform movement is a desire to improve health care for consumers. Thus, Williams says that patients deserve "expedited access to breakthrough products" and that clinical trials need to be "streamlined." Moreover, FDA needs to "see its mission not only as assuring safety but also as facilitating development and access to new therapies and promoting innovation," she adds. "We will put that mission statement into statutory language." Congressional action is also needed if there is to be any relief from the requirement for more than one phase III clinical trial before most therapeutic products can be fully approved.

Congress plans to make FDA more accountable to the public, Williams says. By setting "performance standards" and requiring FDA officials to submit annual reports, Congress could, it hopes, keep a tighter rein on the agency. Another part of the congressional reform plan is to "facilitate communication" and "create a collaborative atmosphere," among FDA, industry, and patient groups, she says.

Senator Edward Kennedy (DMA) tends to emphasize FDA's role of protecting consumers. Nonetheless, Kennedy, who is the senior Democratic member of the Senate Committee on Labor and Human Resources, also wants to see the agency "speed the approval of safe and effective products and eliminate antiquated and unnecessary burdens on industry," says staff member David Nexon.

One such step, according to Nexon, will be to "liberalize export laws" which currently prevent U.S. biotechnology companies from exporting products for nondomestic markets until those products are approved by FDA. Such measures will help dissuade manufacturers from moving outside the country, says John Cohrssen, staff member to the House of Representatives Committee on Commerce, which is chaired by Representative Thomas Bliley Jr. (R-VA). The pressure to build facilities in countries with friendlier regulatory agencies is particularly acute for medical device companies, because their products are often held up for extended periods at FDA, Cohrssen says.

A step that would help in speeding FDA reviews would be to "open up the process by using extramural reviewers," Cohrssen says. A few years ago, the idea of contracting out some of FDA's work was widely criticized as a "bad idea," he says. "Today it's considered a 'modest proposal.'
We want research to progress more rapidly and FDA to have flexibility. So some functions can be done by entities beyond the staff."

Another reform that would be particularly welcome to the biotechnology industry would be to permit easier "off-label" uses of approved products, notes Steve Jenning, a staff member with the House Committee on Commerce. This could allow physicians to test drugs on an "experimental" basis in new indications without establishing full-blown and costly clinical trials. Making greater use of data obtained and accepting regulatory decisions made outside the United States are other changes that are being seriously considered as FDA reform bills are being drafted.

Over the past decade, the senior Democrat on the Commerce Committee, Ron Wyden (D-OR), and the committee's Republican members have often been worlds apart in their views on FDA. But now, Jenning believes, there is little difference between them. "There is a general consensus on many of these FDA reform issues," he says.

Despite this show of bipartisan agreeableness, however, some proposals affecting FDA still trigger squabbling. On the agency's budget, for example, Republicans hold that cutbacks discourage waste and improve efficiency, but Democrats argue that any cutback would obstruct efforts to accelerate product reviews.

In addition, many members of Congress are still uncomfortable with some of the reform proposals, including "off-label" use, the use of external reviewers, and any significant lessening of data required to prove product safety and efficacy. Moreover, a proposal that calls for virtually eliminating liability lawsuits over any products that FDA has approved probably could not be enacted in the Senate, Williams says. If the FDA reform bill now being drafted becomes encumbered with amendments that try to institute such radical changes, "reform will not happen," she warns. "We should not hold a good bill hostage to a perfect bill." 一Jeffrey L. Fox 